НАУКОВИЙ ВІСНИКК

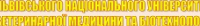

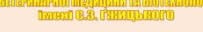

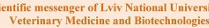
1.2. 11 Minn

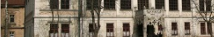
СЕРЯ: ХАРЧОВІ ТЕХНОЛОГ Том 23 № 96 2021

\section{Науковий вісник Дьвівського націонадьного університету} ветеринарної медицини та біотехнодогій імені С.3. Гжицького. Серія: Харчові технологіі

\author{
Scientific Messenger of Lviv National University \\ of Veterinary Medicine and Biotechnologies.
}

Series: Food Technologies doi: 10.32718/nvlvet-f9615

https://nvlvet.com.ua/index.php/food

UDC 504.06

\title{
Main aspects of environmental protection from urban noise
}

\author{
V. M. Storozhuk ${ }^{1}$, B. Y. Kshyvetskyy ${ }^{1}$, O. M. Mayevska ${ }^{1}$, H. V. Somar ${ }^{1}$, I. A. Sokolovskyi ${ }^{1}$, A. V. Melnikov $^{2}$ \\ ${ }^{1}$ Ukrainian National Forestry University, Lviv, Ukraine \\ ${ }^{2}$ IT Step University, Lviv, Ukraine
}

Article info

Received 03.06.2021

Received in revised form 06.07 .2021

Accepted 07.07.2021

Ukrainian National Forestry University, Gen. Chuprynka St., 103 Lviv, 79057, Ukraine. $\mathrm{Tel}:+38-032-238-45-02$

E-mail:viktor.storozhuk@nltu.edu.ua

IT Step University,

Zamarstynivska Str., 83A,

Lviv, 79011, Ukraine.

Tel.: +38-032-240-38-51

E-mail:eresearch@ukr.net
Storozhuk, V. M., Kshyvetskyy, B. Y., Mayevska, O. M., Somar, H. V., Sokolovskyi, I. A., \& Melnikov, A. V. (2021). Main aspects of environmental protection from urban noise. Scientific Messenger of Lviv National University of Veterinary Medicine and Biotechnologies. Series: Food Technologies, 23(96), 88-92. doi: 10.32718/nvlvet-f9615

The main sources of noise pollution in modern cities, that generate significant levels of sound pressure, which significantly, sometimes at times exceed permissible noise levels have been identified. The consequences of the negative impact of noise of the urban environment on the human body, fauna and flora are described. The sanitary-hygienic, engineering-technical, architectural-planning, construction-acoustic and economic-social aspects of scientific researches concerning protection of the environment from noise pollution are singled out. The main methods and ways to reduce urban noise are described, among which are: reducing the sound power level of existing equipment and vehicles, or replacing them with less noisy ones, and during design-taking measures to minimize noise emissions from machines; carrying out timely cleaning, adjustment, repair of machines, mechanisms and equipment, restriction or complete prohibition of noisy works and operation of the most intensive noise sources at night; rational orientation of the noise source or place of noise radiation, taking into account the direction indicator; placement of noise sources and objects of protection - at the maximum possible distance from each other; the use of building structures with improved sound insulation, the use of sound-absorbing materials for lining the enclosing structures of buildings and structures; zoning of sources and objects of protection, application of territorial gaps, noise protection buildings, acoustic screens and strips of greenery. It was found that the maximum possible impact on noise pollution of modern cities and surrounding areas can be achieved in the case of integrated application of methods, means of protection against acoustic blocking of the duration, direction and use of noise emissions in its sources and through noise level on the way to its spread, as well as through the implementation of appropriate organizational and technical measures.

Key words: noise pollution, sound level, negative influence, reduction methods, environment.

\section{Основні аспекти захисту навколишнього середовища від міського шуму}

\author{
В. М. Сторожук ${ }^{1}$, Б. Я. Кшивецький ${ }^{1}$, О. М. Маєвська ${ }^{1}$, Г. В. Сомар ${ }^{1}$, I. А. Соколовський ${ }^{1}$, \\ О. В. Мельников
}

${ }^{1}$ Національний лісотехнічний університет Украӥни, м. Львів, Украӥна

${ }^{2}$ IT СТЕП Університет, м. Львів, Україна

\begin{abstract}
Виявлено основні джерела шумового забруднення сучасних міст, шьо генерують значні рівні звукового тиску, які суттєво, іноді у рази, перевищують допустимі рівні шуму. Описано наслідки негативного впливу шуму на організм людини, фауну та флору урбанізованого середовища. Виокремлено санітарно-гігієнічний, інженерно-технічний, архітектурно-планувальний, будівельноакустичний та економіко-соціальний аспекти наукових досліджень щодо захисту довкілля від шумового забруднення. Охарактеризовані основні методи та способи зниження міського шуму, серед яких: зниження рівня звукової потужності наявного устаткування та транспортних засобів, або їх заміна на менш шумні, а під час проектування - вжиття заходів для мінімізацї емісії шуму машинами; проведення своєчасного чищення, мащення, налагодження, ремонту машин, механізмів та устаткування, обмеження або повна заборона проведення шумних робіт і експлуатації найбільш інтенсивних джерел шуму в нічний час; раціональне орієнтування джерела шуму або місия випромінювання шуму з урахуванням показника спрямованості; розміщення джерел шуму та
\end{abstract}


об'єктів захисту - на максимально можливій віддалі один від одного; використання будівельних конструкцій з покращеною звукоізоляцією, застосування звукопоглинальних матеріалів для личкування огороджувальних конструкцій будівель $і$ споруд; зонування $i$ районування джерел $і$ об'єктів захисту, застосування територіальних розривів, шумозахисних будівель, акустичних екранів та смуг зелених насаджень. 3'ясовано, що максимальний ефект щуодо зниження шумового забруднення навколишнього природного середовища сучасних міст та прилеглих територій може бути досягнутий у разі комплексного застосування методів, способів $i$ засобів захисту від акустичного забруднення довкілля, спрямованих $і$ на зниження емісії шуму в джерелі його виникнення, і на зниження рівня шуму на шляху його поширення, а також шляхом реалізації відповідних організаційно-технічних заходів.

Ключові слова: шумове забруднення; рівень звуку; негативний вплив; методи зниження; довкілля.

\section{Вступ}

Від шумового забруднення міст сьогодні потерпають як населення, так і представники фауни та флори. Експлуатація промислових об'єктів, зростання кількості транспортних засобів, інтенсивне будівництво призводять до розширення контактів між техногенним середовищем міста і природним середовищем i, як наслідок, до значного шумового забруднення. До найбільших джерел шуму належать аеропорти, залізничні вузли та станції, автовокзали i автогосподарства, мотелі та кемпінги, трейлерні парки, логістичні центри, об'єкти будівництва, промислові об'єкти і потужні енергетичні установки, а також масові спортивні заходи на стадіонах, у парках, громадські заходи (мітинги, концерти на відкритих майданчиках, масові святкові дійства) тощо.

Постійне зростання насиченості міського середовища джерелами емісії шуму зумовлює актуальність даної проблеми, як для людини, так і для представників тваринного та рослинного світу сучасних міст $\mathrm{i}$ приміських територій. Об'єктом нашого дослідження $\epsilon$ шумове забруднення міського середовища. Предметом дослідження - методи і способи зменшення емісії міського шуму та його зниження на шляху поширення.

Мета роботи - визначити оптимальні підходи щодо мінімізації шумового забруднення навколишнього природного середовища, що виникає внаслідок життедіяльності сучасних міст.

Для досягнення мети визначено основні завдання дослідження:

- здійснити аналіз літературних публікацій, присвячених питанням шумового забруднення міст;

- встановити рівні шумового забруднення міського середовища та наслідки для мешканців міст;

— розглянути особливості методів зниження шуму у містах;

— підібрати оптимальні варіанти застосування методів та способів шумозахисту міського середовища.

Аналіз останніх публікацій за проблематикою та визначення невирімених раніше частин загальної проблеми. Питаннями щодо шумового забруднення селитебних території займалась низка дослідників у різні часи, де розглядались причини шумового забруднення міст, його наслідки для природного середовища, методи дослідження шуму, а також методи, способи та засоби шумозниження (Storozhuk, 2003; Storozhuk et al., 2006; Harding et al., 2013; Magrini \& Lisot, 2015; Djercan et al., 2019; Barrigón Morillas et al., 2018).

Значний рівень і тривала дія міського шуму значно погіршує якість умов життєдіяльності населення, порушує умови відпочинку, створює дискомфорт, впливає збудливо на центральну нервову і серцевосудинну системи, спричиняє напруження захисноадаптаційних механізмів в організмі людини, сприяє розвиткові атеросклерозу, виникненню захворювань травного тракту, гіпертонічної хвороби тощо (Storozhuk et al., 2006).

Виявлені залежності між інтенсивністю шуму і захворюваністю населення. Серед мешканців шумних районів міста серцево-судинна захворюваність в кілька разів вища, ніж у жителів більш тихих районів. Рівень даної патології у жінок, що не працюють, але проживають в будинках, де рівень шуму сягає 7075 дБА, у 2-3 рази вищий, ніж у жінок, що проживають в будинках, де середній рівень шуму нижчий за 70 дБА. Згідно санітарних норм рівень звуку, який проникає у житлові приміщення, не повинен перевищувати 30 дБА в нічний час і 40 дБА - у денний час (Nakaz Ministerstva, 2019).

За даними фахівців Інституту громадського здоров'я ім. О. М. Марзєєва НАМН України значна частина (біля 40 \%) загальної площі середньостатистичного міста (з населенням 750 тис. жителів) непридатна для нормального проживання внаслідок значного акустичного забруднення; у містах-мільйонниках мешканці магістральних вулиць піддаються значному шумовому навантаженню, яке може сягати 83-90 дБА (у середньому на 55-87 \% джерелом підвищеного рівня шуму є автотранспорт) (Storozhuk, 2003). Між тим, гранично допустимий рівень шуму на територіях, що прилягають до будинків, впродовж доби становить: 55 дБА від 8 до 22-ї години та 45 дБА - від 22 до 8-ї години (Nakaz Ministerstva, 2019).

\section{Матеріал і методи досліджень}

Аналітична обробка діючих нормативних документів і наукових праць 3 метою узагальнення методів, способів і засобів мінімізації акустичного забруднення навколишнього природного середовища міських територій

\section{Результати та їх обговорення}

Шум справляє негативний вплив не тільки на людей, а також і на флору. Так, під впливом шуму, сповільнюється ріст рослин, у них спостерігається надмірне (іноді навіть повне) виділення вологи через листя, внаслідок чого можливі, як ушкодження клітин, так і загибель всієї рослини. У рослин, які розміщені біля джерел інтенсивного шуму, опадає листя, гинуть квіти, в клітинах можуть відбуватися метаболічні зміни морфологічних ознак і навіть генетичні мутації. Дані 
явища справляють негативний вплив на еволюцію рослин, оскільки у несприятливих умовах виживають переважно мутанти 3 різними відхиленнями від нормального розвитку (кривий стовбур, змінені листки тощо). Внаслідок таких мутацій, особливо в міському середовищі, підвищується кількість дерев мутагенної структури.

Організм представників тваринного світу, як i людський організм, під впливом надмірного шуму зазнає серйозних розладів нервової системи, серцевого ритму, слухового апарату тощо. Спостерігається негативна дія шуму на тварин, риб, комах. До шуму тварини адаптуються повільніше за людей.

Найбільш негативно шум, спричинений антропогенною та техногенною діяльністю, позначається на диких тваринах, зокрема, на мешканцях міських скверів, парків, рекреаційних зон. Більшість тварин уникають акустично забруднених місць, оскільки це порушує нормальний ритм їхньої життєдіяльності, погіршує сон, відлякує здобич. Хворобливо переносять шум риби, особливо у період нересту. Від впливу авіаційного шуму бджоли втрачають здатність орієнтуватися, гинуть личинки бджіл, в пташиних гніздах виникають тріщини в шкаралупі яєць.

Одомашнені свійські тварини дещо призвичаїлися до навколишнього шуму, проте шум і на них справляє негативний вплив. Особливо негативно шумові коливання сприймають кішки, які, переважно, залишають територію, де наявний постійний вплив шуму значної інтенсивності. В умовах підвищеного шуму собаки, найчастіше бійцівських порід, не завжди виконують команди господарів і можуть становити загрозу, як для навколишніх мешканців, так і для самих господарів.

Тварини мають більш розвинені органи чуття; верхня абсолютна межа чутливості їхнього слухового аналізатора знаходиться нижче верхньої межі аналізатора людини, тобто, больовий поріг у багатьох тварин досягається раніше, ніж у людини. Відповідно, інтенсивний шум такі тварини, як коти, собаки, більшість видів птахів сприймають як больові сигнали. Окрім того, шум $є$ небезпечним як для самих представників фауни, що мають вивести приплід, так і для їхнього майбутнього потомства.

Вище наведене свідчить про необхідність здійснення заходів, спрямованих на зниження шумового забруднення сучасних міст і житлових районів зокрема, та навколишнього середовища в цілому до меж, які б відповідали нормам, визначених популяційною екологією.

Проблема зниження шумового забруднення довкілля є багатогалузевою, до вирішення якої залучаються спеціалісти широкого спектру: конструктори, лікарі-гігієністи, будівельники, архітектори, містобудівники, економісти тощо (табл. 1).

\section{Таблиця 1}

Основні аспекти наукових досліджень щодо захисту від шумового забруднення

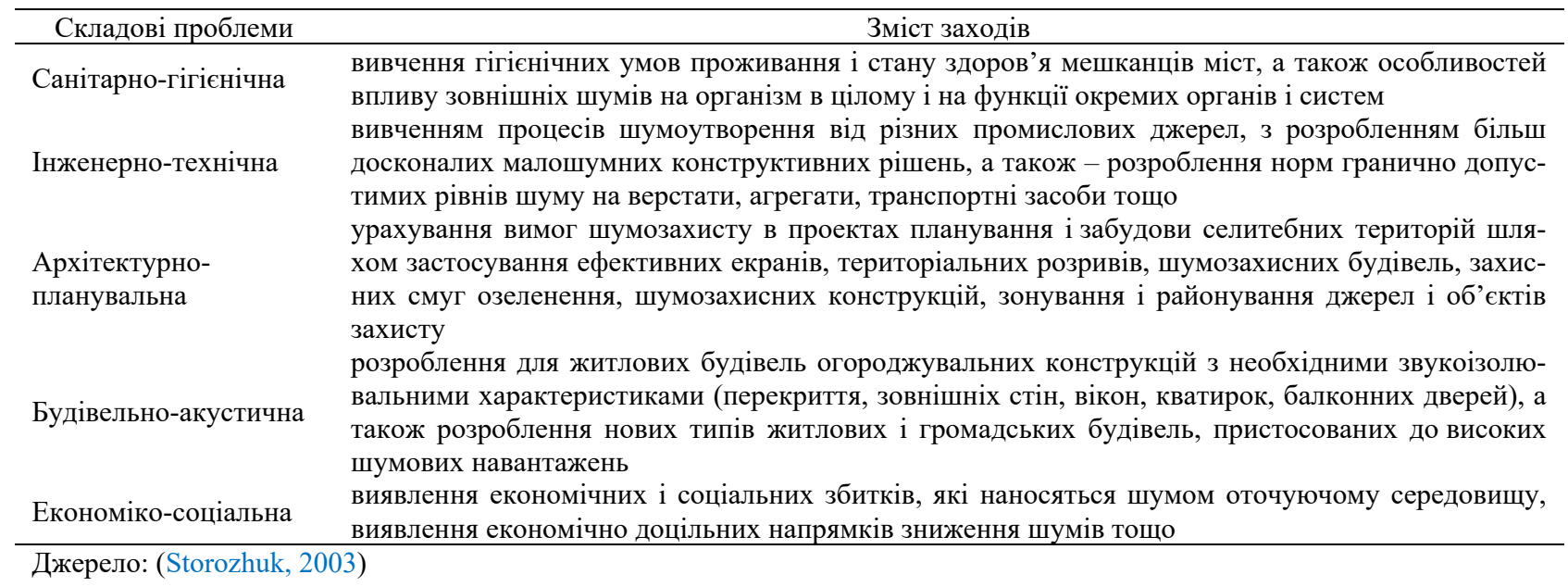

Для зниження шумового забруднення довкілля можуть бути застосовані відповідні заходи:

- зниження рівня звукової потужності джерела шуму, що в умовах експлуатації досягається заміною гучного, застарілого обладнання, а в проектуванні вибором устаткування з кращими шумовими характеристиками, ретельним розрахунком режиму його роботи і т.д.;

- раціональне орієнтування джерела шуму або місця випромінювання шуму відносно об’єкта захисту, - розрахункової точки (РТ), для зниження показника спрямованості (наприклад, 3 цією метою пристрої для забору та випуску повітря і газоповітряної суміші аеродинамічних установок слід встановлювати так, щоб випромінювання шуму відбувалося в протилежну сторону від житлових і громадських будівель);

- розміщення джерела шуму на максимально можливій віддалі від РТ або, навпаки, - розміщення житлової забудови якомога далі від шумного підприємства, тобто за рахунок реалізації комплексу архітектурно-планувальних заходів;

- використання засобів звукопоглинання для виконання акустичного оброблення лунких приміщень, через огороджувальні конструкції яких шум випромінюється в навколишнє середовище; 
— зниження рівня шуму на шляху його поширення від джерела виникнення до РТ;

— здійснення організаційно-технічних заходів, пов'язаних із проведенням своєчасних налагоджень, ремонту, змащування машин і устаткування тощо, обмеженням і повною забороною проведення шумних робіт і експлуатацію найбільш інтенсивних джерел шуму в нічний час (Storozhuk, 2003; Storozhuk et al., 2006; Shushunova et al., 2021).

Зниження шуму в джерелі його виникнення є найбільш дієвим засобом боротьби із шумом виробничого устаткування. Проте досвід підприємств свідчить, що ефективність заходів щодо зниження шуму експлуатованих шумних машин і механізмів часто $є$ недостатньою, саме тому зниження шуму в джерелі слід досягати насамперед на етапах проектування устаткування, боротьбу з промисловими шумами слід починати 3 вишукування можливостей усунення причин шумоутворення в джерелі. Вище зазначені питання слід вирішувати, як для промислових машин, установок, комунікацій і мереж, транспортних засобів, так і для комунальних та тих, що $є$ у приватній власності.

Зниження шуму на шляху його поширення досягається:

— використанням засобів звукоізоляції шляхом застосування таких матеріалів і конструкцій (для зовнішніх стін, вікон, воріт, дверей, трубопроводів і комунікацій, що проходять через огороджувальні конструкції будівель), що можуть забезпечити необхідну звукоізоляцію;

- влаштуванням спеціальних боксів та звукоізолювальних огороджень для розміщення гучного устаткування;

- застосуванням екранів, що перешкоджають поширенню звуку від устаткування, розташованого на території промислового підприємства;

— використанням засобів віброізоляції і вібродемпферування;

- встановленням глушників шуму у повітроходах, каналах і газодинамічних трактах, систем вентиляції, стисненого повітря тощо.

Архітектурно-планувальний аспект шумозахисту довкілля передбачає для зниження рівнів шуму на території або в приміщеннях об'єктів, що захищаються від шуму, низку методів, зокрема - застосування екранів і спеціальних смуг зелених насаджень, які мають комплексний характер захисної дії (Storozhuk, 2001; Storozhuk \& Matvieieva, 2009).

В якості захисних екранів можуть використовуватись штучні і природні елементи рельєфу місцевості (виїмки, земляні кавальєри, насипи, пагорби тощо), будівлі, в приміщеннях яких допускаються рівні звуку більші за 50 дБА, житлові будинки з посиленою звукоізоляцією зовнішніх огороджувальних конструкцій, житлові будинки, у яких зі сторони джерел шуму розташовані вікна підсобних приміщень і однієї житлової кімнати трикімнатних квартир, квартир із більшою кількістю кімнат та різноманітні споруди (пришляхові підпірні, огороджувальні і захисні стінки 3

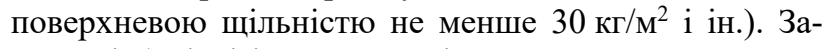
значені будівлі і споруди слід розташовувати вздовж джерел шуму (наприклад, шумних підприємств, тран- спортних магістралей), як правило, у вигляді суцільної забудови. Екрани розміщують між джерелами шуму і об'єктами, що захищаються від шуму.

У разі відсутності між джерелом шуму та об'єктом захисту від шуму зазначених споруд і будівель на шляху поширення звукової енергії слід розташовувати акустичні (шумозахисні) екрани - конструкції 3 підвищеними звукопоглинальними і звукоізолювальними характеристиками (Storozhuk \& Matvieieva, 2009).

Захисні насадження в містах можуть використовуватись як самостійні засоби шумозахисту, так і разом 3 іншими інженерними шумозахисними спорудами (Storozhuk, 2001). Зниження рівня шумового забруднення довкілля у випадку застосування захисних насаджень відбувається внаслідок таких явищ, як розсіювання, поглинання і дифракція звукових хвиль.

Зелену масу крон дерев, яка складається 3 листя різної конфігурації, щільності і орієнтації, можна розглядати як змінно-контрастне фізичне середовище, де безперервно чергуються акустично непрозорі i прозорі елементи середовища. Звукова енергія, потрапляючи 3 повітря в простір, заповнений кронами дерев, переходить в інше середовище - повітрянолистяне, яке має здатність розсіювати і поглинати звукову енергію. Зелені насадження щільного садіння можна розглядати, з певним наближенням, як екранувальний напівпрозорий бар'єр на шляху поширення звукових хвиль за яким утворюється звукова тінь.

Спеціальні смуги зелених насаджень мають комплексний характер захисної дії - забезпечують захист від шуму, вихлопних газів автотранспорту, абсорбування пилу та інших компонентів-полютантів; сприяють покращенню мікрокліматичних показників міського середовища, забезпечують позитивний психологічний і естетичний вплив на населення. Все це значно підвищує соціальну значимість озеленення, як містобудівного засобу шумозахисту.

\section{Висновки}

У роботі запропоновано комплексний підхід у вирішенні проблеми мінімізації шумового забруднення міст: ефективне зниження міського шуму можливе у разі ऑї поетапного вирішення: дослідження емісії шуму, шляхів його поширення, фактичного рівня шуму в селитебній зоні, визначення величини необхідного зниження шуму, вибір (розроблення) оптимальних методів, способів та засобів зниження шумового забруднення та їх реалізація. Перш за все слід дослідити джерела інтенсивного міського шуму, його спектральний склад і спрямованість. Необхідно розробити і впровадити заходи щодо зниження емісії шуму в джерелі виникнення, як найбільш ефективні (стосується, як джерел промислового, так і транспортного та комунального шуму).

Застосування методів зниження шуму на шляху поширення від джерел емісії дозволяє суттєво знизити рівень акустичного забруднення довкілля, важливим у даному випадку є архітектурно-планувальний аспект шумозниження. Тут основними елементами є: вибір матеріалів будівельних конструкцій та личкувальних 
матеріалів 3 необхідними звуковідбивальними і звукопоглинальними властивостями; проектування будівель та споруд з урахуванням їх експлуатації у відповідних акустичних умовах; екранування шуму, як спеціальними конструкціями, так і смугами зелених насаджень.

Максимальний ефект у зниженні шумового забруднення міського середовища може бути досягнутий у разі комплексного застосування методів, способів і засобів захисту від акустичного забруднення довкілля. Методи та способи шумозниження, розглянуті у даній роботі, дозволяють суттєво знизити шумове забруднення навколишнього природного середовища, покращити якість життєвого середовища міського населення.

\section{References}

Barrigón Morillas, J. M., Gozalo, G. R., González, D. M. Moraga, P. A., \& Vílchez-Gómez R. (2018). Noise Pollution and Urban Planning. Current Pollution Reports, 4, 208-219. doi: 10.1007/s40726-018-0095-7.

Djercan, B., Bjelajac, D., Bubalo Živković, M., \& Gatarić, D. (2019). Noise: The Disease of Urban Environments: Management and Protection Measures. Zbornik radova Departmana za geografiju, turizam i hotelijerstvo, 48(2), 127-142. doi: 10.5937/ZbDght1902127D.

Harding, A. H., Frost, G. A., Tan, E., Tsuchiya, A., \& Mason, H. M. (2013). The Cost of HypertensionRelated Ill-Health Attributable to Environmental Noise. Noise Health, 15(67), 437-445. doi: 10.4103/1463-1741.121253.
Magrini, A., \& Lisot, A. (2015). Noise Reduction Interventions in the Urban Environment as a form of Control of Indoor Noise Levels. Energy Procedia, 78, 1653-1658. doi: 10.1016/j.egypro.2015.11.246.

Pro zatverdzhennia Derzhavnykh sanitarnykh norm dopustymykh rivniv shumu $\mathrm{V}$ prymishchenniakh zhytlovykh ta hromadskykh budynkiv i na terytorii zhytlovoi zabudovy: Nakaz Ministerstva okhorony zdorovia Ukrainy vid 22.02.2019 № 463. URL: https://zakon.rada.gov.ua/laws/show/z0281-19\#Text (in Ukrainian).

Shushunova, N., Feoktistova, O., \& Shushunova, T. (2021). Efficiency of Reducing Noise Pollution by Using the Greening System of Buildings. IOP Conference Series: Materials Science and Engineering, 1079(3), 042001. doi:10.1088/1757-899X/1079/4/042001.

Storozhuk, V. M. (2001). Zakhysni smuhy ozelenennia yak odyn iz aspektiv arkhitekturno-planuvalnoho metodu znyzhennia shumovoho zabrudnennia mist. Nauk. visn. NLTU Ukrainy, 11(4), 198-203 (in Ukrainian).

Storozhuk, V. M. (2003). Vyrobnychyi shum: pryroda ta shliakhy znyzhennia. K.: Osnova (in Ukrainian).

Storozhuk, V. M., \& Matvieieva, H. A. (2009). Arkhitekturno-planuvalnyi metod znyzhennia shumovoho zabrudnennia mist: ekranuvannia shumu. Nauk. visn. NLTU Ukrainy, 19(2), 82-85 (in Ukrainian).

Storozhuk, V. M., Batluk, V. A., \& Nazaruk, M. M. (2006). Promyslova ekolohiia. Lviv: Ukrainska akademiia drukarstva (in Ukrainian). 